\title{
ГЕНДЕРНІ ОСОБЛИВОСТІ ЗМІН ФУНКЦІОНАЛЬНОГО СТАНУ ПЕЧІНКИ У ХВОРИХ НА ІШЕМІЧНУ ХВОРОБУ СЕРЦЯ В ПОСДНАННІ 3 НЕАЛКОГОЛЬНОЮ ЖИРОВОЮ ХВОРОБОЮ ПЕЧІНКИ НА ТЛІ ПРИЙОМУ АТОРВАСТАТИНУ
}

Львівський національний медичний університет імені Данила Галицького

Резюме. Обстежено 50 пацієнтів 3 ішемічною хворобою серця в поєднанні з неалкогольною жировою хворобою печінки, яких за гендерними ознаками розподілено на дві групи, що складались 330 чоловіків та 20 жінок. Усім проводили загальноклінічне обстеження, визначення ліпідного спектра крові та рівня печінкових трансаміназ, ультрасонографію внутрішніх органів та ${ }^{13} \mathrm{C}-$ метацетиновий дихальний тест. Усім пацієнтам призначали аторвастатин у дозі 40 мг 1 раз на добу протягом шести місяців. Виявили достовірне зниження

Вступ. Гендерні особливості перебігу ішемічної хвороби серця (IXC) - одне із ключових питань кардіології, яке необхідно враховувати при діагностиці та лікуванні пацієнтів чоловічої та жіночої статі. [6-9]. IXC часто виникає на тлі ожиріння в поєднанні з неалкогольною хворобою печінки, що погіршує перебіг даної коморбідної патології [3, 12]. Діагностичні алгоритми лікування ішемічної хвороби, які добре підходять для чоловіків, $є$ менш придатними для жінок молодого і середнього віку з низьким і проміжним ризиком серцево-судинних захворювань $[4,5,10]$. У чоловіків спостерігається більш виражений вплив ліпідознижуючих препаратів на порушення функціонального стану печінки при IXC, ніж у жінок $[6,11]$.

Діагностика порушення функції печінки у хворих на IXC зазвичай базується на оцінці рівня печінкових трансаміназ, які не завжди відображають зміни, що виникають при розвитку неалкогольної жирової хвороби печінки (НАЖХП) (стеатоз, стеатогепатит та фіброз). Окрім того, підвищений рівень трансаміназ часто супроводжується “трансамінітом" - синдромом «ухилення» печінкових ферментів у кров, що розвивається на тлі прийому статинів при порушенні ліпідних компонентів мембран гепатоцитів [2].

Одним із найбільш інформативних методів дослідження функціонального стану печінки $є$ $13 \mathrm{C}$ - метацетиновий дихальний тест (13СМДТ). Його застосовують для вимірювання метаболічної ємності печінки та кумулятивних доз на 40-й та 120-й хвилинах 3 метою визначення відсоткового співвідношення кількості функціонуючих гепатоцитів [1].

Мета дослідження. Дослідити гендерні особливості змін функціонального стану печінки у хворих на IXC, у поєднанні з НАЖХП, після ліпідознижувальної терапії статинами.

Матеріал і методи. У дослідження включено 50 пацієнтів з IXC, у поєднанні з НАЖХП та виявленою дисліпідемією, що вимагала прове- метаболічної ємності печінки ( $<0,05)$ та кумулятивної дози на 40 та 120 хвилинах $(\mathrm{p}<0,01)$ у чоловіків порівняно 3 жінками. Встановлено, що ІМТ у жінок був достовірно вищим, ніж у чоловіків $(\mathrm{p}<0,01)$. Рівень печінкових трансаміназ у чоловіків та жінок достовірно не відрізнявся.

Ключові слова: ішемічна хвороба серця, неалкогольна жирова хвороба печінки, аторвастатин, ${ }^{13} \mathrm{C}-$ метацетиновий дихальний тест, гендерні особливості.

дення статинотерапії. Серед них чоловіків було 30 (60 \%), жінок - 20 (40\%). Середній вік хворих становив $(58,06 \pm 1,29)$ років. Тривалість захворювання в середньому складала $(5,22 \pm 0,51)$ років. Індекс маси тіла у чоловіків в середньому скла-

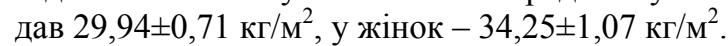

Усім хворим проводили загальноклінічні, лабораторні та інструментальні дослідження (антропометрію, визначення ліпідного спектра крові та рівня печінкових трансаміназ, електрокардіографію, ехокардіографію, ультрасонографію внутрішніх органів, ${ }^{13} \mathrm{C}$ - метацетиновий дихальний тест).

Під час проведення антропометрії усім пацієнтам вимірювали зріст та масу тіла, вираховуючи індекс маси тіла (IMT) за формулою Кетле: $\mathrm{IMT}=$ маса тіла (кг)/зріст $\left(\mathrm{M}^{2}\right)$.

Критеріями включення в дослідження були верифікована IXC (стабільна стенокардія, постінфарктний кардіосклероз), рівень загального холестерину більше 5 ммоль/л, вміст ХС ЛПНГ більше 3 ммоль/л, концентрація тригліцеридів сироватки крові не більше 3,5 ммоль/л.

Діагноз IXC встановлювали на підставі попередньо проведеної коронарографії, раніше перенесеного інфаркту міокарда чи позитивної проби під час тредміл-тесту.

Для діагностики абдомінального типу ожиріння, згідно з рекомендаціями International Diabetes Federation (2005), вимірювали окружність талії (ОТ) на рівні пупка та проводили оцінку цього показника абдоманільного ожиріння (окружність талії в чоловіків > 94 см, у жінок > $80 \mathrm{~cm})$.

Ліпідний спектр крові оцінювали за вмістом загального холестерину сироватки крові (3X), тригліцеридів (ТГ), холестерину ліпопротеїдів низької густини (ХС ЛПНГ) та холестерину ліпопротеїдів високої густини (ХС ЛПВГ). Активність аланінової трансамінази (АЛТ) та аспарагі- 
нової трансамінази (АСТ) сироватки крові визначали загальноприйнятими методиками.

Ультрасонографію гепатобіліарної системи проводили натще на апараті Philips HDI - 15003 датчиком для сканування із частотою 3,5 мГц. Жирову інфільтрацію печінки діагностували за умови збільшення розмірів печінки, дифузного однорідного підвищення її ехогенності, наявності ефекту дистального затінення, розширенні діаметра ворітної вени.

Функціональний стан мікросомальних ензимних систем гепатоцитів визначали за допомогою ${ }^{13} \mathrm{C}$-метацетинового дихального тесту, перорально призначаючи 75 г метацетину, міченого нерадіоактивним ізотопом вуглецю ${ }^{13} \mathrm{C}$.

При призначенні статинотерапії усіх хворих, залежно від гендерних особливостей, розподілили на дві групи. До першої групи увійшло 30 пацієнтів чоловічої статі, другу групу склали 20 пацієнтів жіночої статі. Усім хворим призначали аторвастатин у дозі 40 мг 1 раз на добу протягом шести місяців.

Статистичну обробку отриманих результатів проводили за допомогою комп'ютерної програми "Microsoft Excel" 3 використанням t-критерію Стьюдента.

Результати дослідження та їх обговорення. За даними ультрасонографії у 75 \% пацієнтів спо- стерігалося збільшення розмірів печінки, гіперехогенність паренхіми та гіпоехогенність портальних судин (реверс контрасту).

Призначення протягом шести місяців аторвастатину в дозі 40 мг 1 раз на добу пацієнтам 3 IXC, у поєднанні з НАЖХП та дисліпідемією, дозволило утримувати рівень загального холестерину, ХС ЛПНГ як у чоловіків, так і в жінок, у межах норми, хоча вміст тригліцеридів був дещо підвищений. Водночас, не спостерігалося патологічного збільшення рівнів печінкових трансаміназ після тривалого прийому аторвастатину, що дозволило дійти попереднього висновку, що статинотерапія не чинить суттєвого впливу на функцію гепатоцитів.

Окрім того, рівень печінкових трансаміназ (АЛТ, АСТ) у чоловіків та жінок достовірно не відрізнявся (табл. 1).

Тому важливим було оцінити функціональний стан мікросомальних ензимних систем гепатоцитів за допомогою ${ }^{13} \mathrm{C}$ - метацетинового дихального тесту з урахуванням гендерних відмінностей.

Результати дослідження показали, що при оцінці ${ }^{13} \mathrm{C}$ - метацетинового тесту виявлялося вірогідне зниження метаболічної ємності печінки та кумулятивної дози на 40-й та 120-й хвилинах у чоловіків порівняно $з$ жінками. При цьому вста-

Таблиця 1

Показники ліпідограми та печінкових трансаміназ у пацієнтів 3 ішемічною хворобою серця в посднанні з неалкогольною жировою хворобою печінки залежно від гендерних особливостей

\begin{tabular}{|c|c|c|}
\hline Показники ліпідограми & $\begin{array}{c}\text { I група (чоловіки) } \\
\mathrm{n}=30\end{array}$ & $\begin{array}{c}\text { II група (жінки) } \\
\mathrm{n}=20\end{array}$ \\
\hline Загальний холестерин & $4,56 \pm 0,17^{*}$ & $4,85 \pm 0,30^{*}$ \\
\hline Ліпопротеїни низької густини & $2,73 \pm 0,20^{*}$ & $2,81 \pm 0,28^{*}$ \\
\hline Ліпопротеїни високої густини & $1,1 \pm 0,05^{*}$ & $1,17 \pm 0,04^{*}$ \\
\hline Тригліцериди & $1,84 \pm 0,15^{*}$ & $2,07 \pm 0,17^{*}$ \\
\hline АЛТ & $0,55 \pm 0,03^{*}$ & $0,46 \pm 0,03^{*}$ \\
\hline АСТ & $0,42 \pm 0,02^{*}$ & $0,49 \pm 0,03^{*}$ \\
\hline
\end{tabular}

Примітка. $\mathrm{n}$ - кількість пацієнтів у групі; * - $<<0,05$

Таблиця 2

Показники ${ }^{13} \mathrm{C}$ - метацетинового дихального тесту та індексу маси тіла у пацієнтів 3 ішемічною хворобою серця в посднанні з неалкогольною жировою хворобою печінки залежно від гендерних особливостей

\begin{tabular}{|c|c|c|}
\hline $\begin{array}{c}\text { Показники }{ }^{13} \mathrm{C}-\text {-метацетинового } \\
\text { дихального тесту }\end{array}$ & $\begin{array}{c}\text { I група (чоловіки) } \\
\mathrm{n}=30\end{array}$ & $\begin{array}{c}\text { II група (жінки) } \\
\mathrm{n}=20\end{array}$ \\
\hline $\begin{array}{c}\text { Швидкість метаболізму печінки (\% } \\
{ }^{13} \mathrm{C} / \text { г/од) }\end{array}$ & $16,31 \pm 0,98$ & $19,98 \pm 1,45^{*}$ \\
\hline $\begin{array}{c}\text { Кумулятивна доза на } 40 \text {-й хвилині } \\
\left(\%{ }^{13} \mathrm{C}\right)\end{array}$ & $7,39 \pm 0,45$ & $9,26 \pm 0,67^{*}$ \\
\hline $\begin{array}{c}\text { Кумулятивна доза на 120-й хвилині } \\
\left(\%{ }^{13} \mathrm{C}\right)\end{array}$ & $14,10 \pm 0,94$ & $19,02 \pm 1,41^{* *}$ \\
\hline ІМТ & $29,94 \pm 0,71$ & $34,25 \pm 1,07^{* *}$ \\
\hline
\end{tabular}

Примітка. $\mathrm{n}$ - кількість пацієнтів у групі; * $-\mathrm{p}<0,05 ; * *-\mathrm{p}<0,01$ 
новлено, що IMT у жінок був достовірно вищим, ніж у чоловіків ( $<0,01)$ (табл. 2).

Причинами, що зумовлюють зниження детоксикаційної функції печінки, можуть бути надмірна маса тіла, кластери шкідливих звичок, хронічні захворювання печінки, токсична дія деяких фармакологічних препаратів [12].

Отримані дані більш ретельно оцінюють функціональний стан печінки, враховуючи не лише рівень печінкових трансаміназ, але й стан мікросомальних ензимних систем гепатоцитів для найбільш оптимального довготривалого призначення аторвастатину з метою вторинної профілактики.

\section{Висновки}

1. За гендерними ознаками, швидкість метаболізму печінки та іiї кумулятивна доза на 40-й і 120 -й хвилинах у пацієнтів 3 ішемічною хворобою серця, у поєднанні 3 неалкогольною жировою хворобою печінки, є достовірно кращими у жінок, ніж у чоловіків.

2. Рівень печінкових трансаміназ у пацієнтів чоловічої та жіночої статі достовірно не відрізнявся, тому показники аланінової трансамінази i аспарагінової трансамінази не можуть бути головним маркером оцінки функціонального стану печінки у хворих на ішемічну хворобу серця, у поєднанні 3 неалкогольною жировою хворобою печінки, при призначенні їм статинотерапії.

3. Перед призначенням статинів 3 метою вторинної профілактики пацієнтам 3 ішемічною хворобою серця, у поєднанні 3 неалкогольною жировою хворобою печінки, слід попередньо враховувати функціональний стан гепатоцитів.

4. Рішення щодо доцільності, терміну і дози статинів для лікування пацієнтів 3 ішемічною хворобою серця, у поєднанні з неалкогольною жировою хворобою печінки, повинно прийматися індивідуально щодо кожного пацієнта.

Перспективи подальших досліджень полягають в оцінці функціонального стану печінки за допомогою ${ }^{13} \mathrm{C}$-метацетинового тесту в проміжний та кінцевий періоди (3, 6, 12 місяців) прийому статинотерапії у пацієнтів з ішемічною хворобою серця, у поєднанні $з$ неалкогольною жиро- вою хворобою печінки, для оптимізації шляхів діагностики, профілактики та лікування прогресуючого ураження печінки.

\section{Література}

1. Диагностическая ценность $13 \mathrm{C}$-метацетинового дыхательного теста при некоторых хронических диффузных заболеваниях печени / И.Л. Кляритская, Т.А. Цпяк [и др.] // Сучас. гастроентерол. - 2006. № 5 (31). - С. 4-7.

2. Скляров С.Я. Моніторинг порушень функції печінки у пацієнтів з неалкогольною жировою хворобою печінки на тлі метаболічного синдрому / Є.Я. Скляров, Х.Б. Аксентійчук, Н.В. Курляк // Гепатологія. - 2015. - № 1 (27). - C. 34-41.

3. Association between nonalcoholic fatty liver disease and coronary artery disease / U. Arslan, S. Türkoğlu, S. Balcioğlu [et al.] // Coron Artery Dis. - 2007. - Sep. Vol. 18 (6). - P. 433-436.

4. Jaguszewski M. A signature of circulating microRNAs differentiates takotsubo cardiomyopathy from acute myocardial infarction / M. Jaguszewski, J. Osipova, J.R. Ghadri // Eur. Heart J. - 2014. - Vol. 35. - P. 999-1006.

5. Templin C. Clinical features and outcomes of Takotsubo (stress) cardiomyopathy / C. Templin, J.R. Ghadri, J. Diekmann // N. Engl. J. Med. - 2015. - Vol. 373. P. 929-938.

6. Gender in cardiovascular diseases: impact on clinical manifestations, mamagement and outcomes / V. RegitzZagrosek, S. Oertelt-Prigione, E. Prescott [et al.] // Eur. Heart J. - 2016. - Jan 1. - Vol. 37 (1). - P. 24-34.

7. Handbook of Clinical Gender in Medicine / K. SchenckGustafsson, P.R. DeCola, D.W. Pfaff, D.S. Pisetsky. Basel: Karger, 2012. - P. 1-16.

8. Legato M. Principles of Gender-Specific Medicine M. Legato. - Amsterdam, Boston: Elsevier, 2010. - 774 p.

9. Oertelt-Prigione S. Sex and Gender Aspects in Clinical Medicine / S. Oertelt-Prigione, V. Regitz-Zagrosek. London: Springer Verlag, 2011. - 63 p.

10. Regitz-Zagrosek V. Pregnancy-related spontaneous coronary artery dissection / V. Regitz-Zagrosek, K. Jaguszewska, K. Preis // Eur. Heart J. - 2015. - Vol. 36. P. 2273-2274.

11. Statins in the Treatment of Dyslipidemia in the Presence of Elevated Liver Aminotransferase Levels: A Therapeutic Dilemma / R.M. Calderon, X. Luigi, M.D. Cubeddu [et al.] // Mayo Clin Proc. - 2010. - Apr. - Vol. 85 (4). P. 349-356.

12. Sun L. Association between non-alcoholic fatty liver disease and coronary artery disease severity / L. Sun, S.Z. Lü // Chin. Med. J. (Engl). - 2011. - Mar. - Vol. 124 (6). - P. 867-872.

\section{ГЕНДЕРНЫЕ ОСОБЕННОСТИ ИЗМЕНЕНИЯ ФУНКЦИОНАЛЬНОГО СОСТОЯНИЯ ПЕЧЕНИ У БОЛЬНЫХ С ИШЕМИЧЕСКОЙ БОЛЕЗНЬЮ СЕРДЦА ВМЕСТЕ С НЕАЛКОГОЛЬНОЙ ЖИРОВОЙ БОЛЕЗНЬЮ ПЕЧЕНИ НА ФОНЕ ПРИЕМА АТОРВАСТАТИНА}

\section{Е.Я. Скляров, А.Ю. Барнетт, Н.В. Курляк}

Резюме. Обследовано 50 пациентов с ишемической болезнью сердца в сочетании с неалкогольной жировой болезнью печени, которые по гендерным признакам разделены на две группы, состоящие из 30 мужчин и 20 женщин. Всем проводили общеклиническое обследование, определение липидного спектра крови и уровня печеночных трансаминаз, ультрасонографию внутренних органов и 13С-метацетиновий дыхательный тест. Всем пациентам назначали аторвастатин в дозе 40 мг 1 раз в сутки в течение шести месяцев. Обнаружили достоверное снижение метаболической емкости печени $(\mathrm{p}<0,05)$ и кумулятивной дозы на 40 -й и 120 -й минутах $(\mathrm{p}<0,01)$ у мужчин по сравнению с женщинами. Установлено, что ИМТ у женщин был достоверно выше, чем у мужчин $(\mathrm{p}<0,01)$. Уровень печеночных трансаминаз у мужчин и женщин достоверно не отличался.

Ключевые слова: ишемическая болезнь сердца, неалкогольная жировая болезнь печени, аторвастатин, 13Сметацетиновий дыхательный тест, гендерные особенности. 


\section{GENDER DIFFERENCES AND FUNCTIONAL STATE OF THE LIVER IN PATIENTS WITH CORONARY ARTERY DISEASE ASSOCIATED WITH NON-ALCOHOLIC FATTY LIVER DISEASE DURING ATORVASTATIN TREATMENT}

\section{Ye.Ya. Sklyarov, O.Yu. Barnett, N.V. Kyrlyak}

Abstract. The study involved 50 patients with coronary heart disease associated with nonalcoholic fatty liver disease, groups were formed according to gender split and consisted of 30 men and 20 women. During our scientific study we performed clinical examination of all patients, blood lipid spectrum and liver transaminases evaluation. All patients underwent ultrasonography and methacetine ${ }^{13} \mathrm{C}$-breath test. The patients of both groups, were assigned to atorvastatin $40 \mathrm{mg}$ per day during 6 months. There was significant reduction in the metabolic capacity of the liver $(r<0,05)$ and cumulative doses of 40 and 120 minutes $(r<0,01)$ in men compared to women. The results also showed that BMI in women was significantly higher than in men $(r<0,01)$. The level of liver enzymes in men and women did not differ significantly

Key words: coronary heart disease, nonalcoholic fatty liver disease , atorvastatin , ${ }^{13} \mathrm{C}$ - breath test methacetine , gender.

Danylo Halytsky National University (Lviv)

Рецензент - проф. Т.О. Ілащук

(С Є.Я. Скляров, О.Ю. Барнетт, Н.В. Курляк, 2016
Buk. Med. Herald. - 2016. - Vol. 20, № 2 (78). - P. 158-161

Надійшла до редакції 31.03.2016 року 